\title{
Strengthening the Political Rights of the EU Citizens in the Framework of the European Citizens' Initiative: Brief Analyse of Certain Citizens' Initiatives
}

\section{Oana - Mariuca Petrescu}

$P h D$, postdoctoral researcher within the European Integration Research Team Faculty of Law, University of Deusto, Bilbao, Spain e-mail: oana.petrescu@deusto.es

\author{
Doi:10.5901/ajis.2013.v2n9p414
}

\begin{abstract}
Regulation (EU) No.211/16th February 2011 on the European Citizens' Initiative (ECI), as one of the major innovations of the Treaty of Lisbon, represents the first supranational instrument of direct democracy that took effect on April 1, 2012, creating the direct legal link between the European Union citizens and the European institutions. Within the present paper we will try to analyse briefly certain citizens' initiatives that have been already published on the official website of the European Commission where the online collection of a million signatures is still running, bearing in mind the important role of the citizens as "coauthors" of the law within the European decision-making process, without forgetting to make a short overview of the European Citizens' Initiative instrument.Even though it is too early to give an opinion whether this new instrument will become or not a useful tool for citizens and their democratic participation into the European political life, from our point of view this participation will increase the responsibility of the citizens to be more active by submitting proposals that concern their current life in all the subject matters which are under the Commission's legislative competence. The citizens' efforts will be doubled by the EU institutions and the civil society organizations that can play a significant role in providing the infrastructure and assistance to the $\mathrm{ECl}$ organizers to ensure that the EU citizens are afforded to use their new right in the best conditions and without no obstacles in a more inclusive and democratic Europe.
\end{abstract}

Keywords: citizenship, Treaty of Lisbon, Regulation, political rights, right to initiative

\section{General remarks}

For a long time, the "political voice" of the European citizens was not taken into consideration because of various reasons (the society, the politicians, the economic and political situation etc.) which determined a serious disconnection between the citizens and the decision-making authorities at the level of the European Communities ${ }^{1}$. Because of that, the general perception was that within the Communities was "implemented" a democratic deficit and the citizens did not have the theoretical and practical tools to "fight" against this deficit.

In order to change this unjust situation and to give the opportunity for the European citizens to express themselves in a way or another, starting with 1970s after a debate led by the Heads of State and Government of the Member States of the European Communities regarding the development of the special rights given to the European citizens, debate which took place in 1974 in Paris (Petrescu, 2013), the European Commission drafted in 1975 a proposal aiming at a future development of the European Community Law from the political point of view, proposal considered to be ambitious to be put in practice in a short time, because its principle aim was to make an "complete assimilation with nationals as regards political rights [which was] desirable in the long term from the point of view of a [democratic] European [Community] (Shaw, 2007)".

Despite of some initiatives and second European legislation drafted and adopted by the European Commission, the Council and the European Parliament, among which "Towards a Europe for Citizens"2"; the 1976 Decision and Act concerning the election of the representatives of the European Parliament by direct universal suffrage by the citizens

\footnotetext{
${ }_{1}^{1}$ Presently, the European Union.

${ }^{2}$ This report was elaborated by Leonard Clemence "Leo" Tindemans, former prime minister of Belgium between 25 April 1974 and 20 October 1978, http://aei.pitt.edu/942/1/political_tindemans_report.pdf.
} 
(Adam, 2007) 3 and "The road to European citizenship" (Chalmers, Davies and Monti, 2007), "no consensus was reached [among the European leaders until] the 1992 Treaty of Maastricht (Adam, 2007)". As it can be seen, the important improvement made by the 1976 documents was not accompanied until the Treaty of Maastricht by a consistent European legislation in the field of political rights because "[at that time] there was no real freedom of movement of voters in European elections (Adam, 2007)".

The few steps made between 1990s and middle of 2000s when the original treaties have been amended several times proved to be insufficient in order to realise an "complete assimilation" of nationals of other Member States with the nationals of the host state concerning the political rights, as it was foreseen by the European Commission, as long as the European citizens continued to have limited political rights, among which I can mention the right to vote in national or regional elections (Shaw, 2007) and to stand in elections in the Member States where they are residents. Therefore, I can say that the European citizens were still unable to participate effectively into the European political life.

Starting from this point and taking into account the relevant amendments brought in 2009 by the Treaty of Lisbon, which marks a reference moment in enhancing the democratic participation of the citizens in the European's legislative process, in the following I will focus on analysing the efforts to strengthen the political rights of the citizens through the amendments brought to the primary and secondary European legislation, all culminating with the adoption of one of the most important European legal instruments, the Regulation (EU) no. 211/20114 on the citizens' initiative.

Finally, I will make a short presentation of few of the relevant citizens' initiatives that have been already registered on the European Commission's website starting with $1^{\text {st }}$ April 2012, as part of the active involvement of the citizens in the legislative process.

\section{The right to initiative and the Regulation (EU) no.211/2011 on the citizens' initiative}

Before 1976 the participation of the citizens in the decision-making process of the former European Communities was quasi - inexistent because of the small number of the initiatives to regulate this participation. Starting with 1976 an important step has been taken when the Decision and Act on European elections by direct universal suffrage by citizens, have been adopted. For the first time we are talking about the democratic participation of the citizens (Petrescu, 2013) or the "participatory" democracy, as defined in doctrine (Schnapper, 1997), in the European political life.

Further improvements have been taken by modifying and amending the original treaties through the Treaty on European Union (1992) ${ }^{5}$ and the Treaty of Amsterdam (1999) where additional political rights ${ }^{6}$ (such as, the right to vote and the right to stand a candidate in the local and regional elections as well as for the European Parliament) have been granted to the European citizens.

Another significant moment in shaping the idea of a "citizens' initiative" is represented by the paper "More democracy in Europe" issued in 2005 by the Democracy International, which is a network specialised on European democracy movements. The said document presented visionary ideas for that moment on the most important elements of the direct democracy (e.g. a direct involvement of the citizens in the legislative procedure; the methods to involve the citizens etc.), comprising in the same time "concrete measures for a citizen-based law-making procedure".

In 2009, after a long and difficult process in recognising the political role of the citizens, the Treaty of Lisbon stipulated in art.10 par. 3 of TEU that "every citizen shall have the right to participate in the democratic life of the Union", encouraging in the same time "the cross-border public debate about [the most relevant] EU policy issues (Gurmai, 2011) $)^{8}$ which cover different fields, such as: economic, political, mass-media, education, etc. In other words, the citizens

\footnotetext{
${ }^{3}$ These documents were signed in Brussels on 20 September 1976 and entered into force on 1 July 1978 after its ratification by all the Member States.

4 Published in Official Journal $L$ series no. 65 of 11.03.2011, http://www.google.com/url?sa=t\&rct=j\&q=\&esrc= s\&source=web\&cd=1\&sqi=2\&ved=0CFcQFjAA\&url=http\%3A\%2F\%2Feurlex.europa.eu\%2FLexUriServ\%2FLexUriServ.do\%3Furi\%3DO J\%3AL\%3A2011\%3A065\%3A0001\%3A0022\%3AEN\%3APDF\&ei=Gy7XT47VBcS50QXDx6SgBA\&usg=AFQjCNH7FVvqt4lypd4aLnBK5 k_RC9mvHg.

${ }^{5}$ http://eur-lex.europa.eu/en/treaties/dat/11992E/tif/JOC_1992_224_1_EN_0001.pdf.

${ }^{6}$ By political rights we may understand a variety of such rights, namely: the right to vote; the right to be elected in the legislative bodies or other representative organs; the right to hold public offices, the right to petition etc. During the present paper we will talk about only the electoral rights: the right to vote and the right to be elected.

7 https://open.dsv.su.se/mod/book/view.php?id=733\&chapterid=5.

8 jeanmonnetchair.uab.cat/docs/ponencia\%20Gurmai.doc.
} 
will participate to the normal political life of the European Union, with no restrictions and with more trust on the democratic system (Ikeda, Kobayashi and Hoshimoto, 2008), in which situation they ask the institutions to make a legislative proposal, as it is provided for in article 11 of TEU, through the European Citizens' Initiative, as one of the four types of participations of citizens (Besson and Utzinger, 2008). Same political rights can be met in articles 39 and 40 of the Charter of Fundamental Rights of the European Union.

Analysing the new role granted to the citizens it is worth to highlight few elements (Ikeda, Kobayashi and Hoshimoto, 2008), as follows:

- the emotional element, when the citizens have the feeling that they are part of a normal society and participate effectively in the decision-making process;

- $\quad$ the cognitive element. In this case citizens realise that their "voice is finally heard" through initiatives and is taken into consideration only when several conditions are met;

- the political element means that the citizens represent the new political "actor" who joined the European institutions in drafting and adopting the secondary legislation of the EU.

I mentioned before that the citizens have eventually recognised the right to initiative only as concern the initiatives drafted in the field of secondary EU legislation, because, as concern the EU Treaties, article $\underline{48}$ of the Treaty on European Union, as amended by the Lisbon Treaty, stipulates very clearly which are the revision procedures (Miller, 2012), who can use the revision procedure (e.g. the Government of any Member State, the European Parliament, the European Commission etc.), to what extent the subjects can use the revision procedure (e.g. to increase or to reduce the competences conferred on the Union in the treaties); which institutions need to be consulted during the revision procedure (e.g. the European Parliament, the European Commission in specific cases, the European Central Bank in the monetary area) etc.

After almost two years from the general provision stipulated in the Treaty of Lisbon, the resolution adopted by the European Parliament in $7^{\text {th }}$ May $2009^{9}$, detailing the guidelines for implementing the citizens' initiative, the proposal of the European Commission adopted in $2010^{10}$ and art.24 of TFEU, in 2011 was adopted the Regulation (EU) of the European Parliament and the Council no.211/2011 on the citizens' initiative, in an area of EU competence, which defines the rules and the procedure governing this new legal instrument. It entered into forced at $1^{\text {st }}$ of April 2012. In other way to say, this tool is represented by the initiative to draft proposals through citizens' committee and then to forward them to the European Commission, because the "decisions shall be taken [by the European institutions, organs, bodies and agencies] as openly and as closely as possible to the citizens" (Article 10 para.3 of TEU) respecting all the legal provisions.

Theoretical, the intention of this legal instrument, with huge political potential for strengthening the democracy in European Union, is to be clear, simple, user-friendly and proportionate to the nature of the citizens' initiative in order to encourage this participation, to make the Union more accessible to the citizens, being also consistent with the Union's values (Besson and Utzinger, 2008). In practice, its uniform implementation is depending on the proper measures taken by the citizens' committees throughout the procedure and in accordance with the Commission Implementing Regulation (EU) No 1179/2011 of 17 November 2011 laying down technical specifications for online collection systems pursuant to Regulation (EU) No 211/2011 on the citizens' initiative.

Taking into account the above mentioned with the view to the Regulation no.211/2011, in the following I will make a presentation ${ }^{11}$ of the most relevant features of it, trying also to respond to few questions: which are the conditions, who can participate, who supports the initiatives and other technical things, as follows:

$>$ No matter the subject of the initiatives, these must be organised by the citizens' committee, which is composed of at least $7 \mathrm{EU}$ citizens who are resident in at least 7 different EU countries, while the members of the European Parliament cannot be counted among the 7 citizens needed to promote the initiative;

$>$ Any initiative must be supported by at least one million EU citizens, coming from at least one quarter of $27 \mathrm{EU}$ member countries (representing from 7 or more EU member countries), while the minimum number of signatories per member country is provided for in the Annex I of the said Regulation;

\footnotetext{
${ }^{9}$ European Parliament Resolution of 7 May 2009 requesting the Commission to submit a proposal for a regulation of the European Parliament and of the Council on the implementation of the citizens' initiative, http://www.europarl.europa.eu/sides/getDoc.do?pubRef=//EP//TEXT+TA+P6-TA-2009-0389+0+DOC+XML+V0//EN.

${ }^{10}$ The proposal was adopted on 31st March 2010.

${ }^{11}$ More details about this initiative can be found on http://ec.europa.eu/citizens-initiative/public/guide.
} 
$>$ The minimum age required to organise and to support an initiative is the voting age for the European Parliament elections, which currently is 18 in every country except Austria, where is 16years. A special situation can be met in Catalonia, the Spanish Autonomous Community "where the right to sign and to promote a legislative initiative is [...] 16 years-old (García, López, Mincheva and Szeligowska, 2012)";

$>$ The citizens' committee has to ask for the registration of their initiative in one of the EU's official languages in an online registry ${ }^{12}$ made available by the European Commission, which has to answer within two months. If the initiative is registered in good conditions, the organisers can ask to add translations of their initiative in other official EU languages as it was the case of several initiatives. From this rule, there are exceptions when the European Commission can refuse to register the proposed initiative when: the composition of the citizens' committee does not follow the rules; the initiative is manifestly outside the scope of European Commission's competences to propose legislation; the initiative is manifestly abusive, frivolous or vexatious or it is manifestly contrary to the EU's fundamental democratic values and principles (Brochure The European Citizens' Initiative, 2011).

> The signatures can be collected either on paper or online, and must comply with the models for the statement of support provided for in Annex III of the Regulation. Before starting to collect the signatures online, the organisers must ask the relevant national authority of the EU Member State to certify their online collection system, while the deadline to reply is one month. Starting from the date when the proposed initiative is registered, the organisers will have only one year to collect these signatures.

$>$ Once the organisers have collected the required number of signatures, they will submit them for verification and certification to the relevant national authority in each country, within a period of three months, and after this moment, the organisers submit their initiative to the European Commission that will have three months to examine it and to decide how to react. After that the European Commission will issue a press release in which it will explain its conclusions on the initiative, what action it intends to take, if any, and its reasoning.

> Starting with $1^{\text {st }}$ April 2015 and every 3 years after that, the European Commission will present a report on the implementation of this Regulation, including the problems indentified, the strong and weak points etc.

\section{Brief description of certain citizens' initiatives}

Making the application of the Regulation (EU) no.211/2011 and taking into account the article 10 of TEU, until 20 June 2013, 16 citizens' initiatives have been registered on the official website of the European Commission, with the deadline of collection of the signatures until June $2014^{13}$.

Making a brief statistic, it is worth to mention that few of the initiatives already registered, have been translated in almost / in all or in few languages, such as:"Fraternité 2020 - Mobility. Progress. Europe." (translated in 23 languages); "End Ecocide in Europe: A Citizens' Initiative to give the Earth Rights" (translated in 20 languages); "Unconditional Basic Income (UBI) - Exploring a pathway towards emancipatory welfare conditions in the EU" (translated in 17 languages); "Let me vote" (translated in 11 languages); "European Initiative for Media Pluralism" (translated in 10 languages), while other initiatives have not been translated yet, namely: "ACT 4 Growth" (the original language is English) or "Pour une gestion responsable des déchets, contre les incinérateurs" (the original language is French).

In the following I will try to make a short description of the relevant citizens' initiatives, that have been already translated in the official languages of the European Union, as they are established in the Regulation no. 1/1958 determining the languages to be used by the former European Economic Community ${ }^{14}$, presently the European Union, taking into account as a main criteria the date when these initiatives have been registered.

a. The first initiative introduced on $9^{\text {th }}$ May 2012 is called "Fraternité 2020 - Mobility. Progress. Europe (F2020)15", having as main goal "to enhance EU exchange programmes - such as Erasmus or the European Voluntary Service (EVS) - in order to contribute to a united Europe based on solidarity among citizens". The collection of signatures is still on going until the $1^{\text {st }}$ November 2013 and it is supported by various professors from

\footnotetext{
12 http://ec.europa.eu/citizens-initiative/public/registration/.

13 http://ec.europa.eu/citizens-initiative/public/initiatives/ongoing.

${ }^{14}$ It was published in Official Journal L 17/ 6.10.1958, as amended by Council Regulation (EC) no. 920/2005 of 13 June 2005, published in Official Journal L 156/3 18.6.2005 and Council Regulation (EC) no 1791/2006 of 20 November 2006, published in Official Journal L 363/20.12.2006, http://eur-lex.europa.eu/LexUriServ/site/en/consleg/1958/R/01958R0001-20070101-en.pdf.

${ }^{15} \mathrm{http}: / /$ ec.europa.eu/citizens-initiative/public/initiatives/ongoing/details/2012/000001; http://en.fraternite2020.eu/summary.html.
} 
prestigious universities (University of Paris 1 Pantheon-Sorbonne, European University Institute, London School of Economics and Political Science, Complutense University of Madrid etc.) or institutions, such as: European Council on Foreign Relations.

The idea that stays behind the initiative is that the EU needs "to re-focus its integration efforts on the level of individual European citizens to build a genuine European union of people, not states. This would also lead to positive economic, social, and cultural effects ${ }^{16}$ ", especially in the time of crisis, by finding ways to increase the mobility promises to help the growth of the society, to eliminate as much as possible the high rate of unemployment within the EU, in particular as concern the persons between 18 and 26.

b. The second initiative is called "High Quality European Education for All17", being registered on $16^{\text {th }}$ July 2012. Its main goal is "to create an Education platform to stimulate debate on how to improve schools and boost the European dimension of education in line with the [Europe 2020 Strategy ${ }^{18}$ ]". The collection of signatures for the present initiative is still on going until the $1^{\text {st }}$ November 2013, and it is supported by NGOs working on diverse aspects of Education or members of the European Parents Association (EPA) or parents of students from various European schools or unions working at European level.

One of the principal objectives envisaged by the organizers of this initiative is to establish a multi-stakeholder discussion/collaboration platform where parents, teachers, students, social partners, educators and decisionmakers will propose, debate and formulate a European policy, including a viable strategy, for a quality, pluralistic and EU 2020-oriented educational model at primary and secondary level for all the European citizens.

c. "End Ecocide in Europe: A Citizens' Initiative to give the Earth Rights 19 " is the third initiative analysed in my paper and registered in $21^{\text {st }}$ January 2013, having as main goal "to invite the European Commission to adopt [the proper] legislation to prohibit, prevent and pre-empt Ecocide, the extensive damage to, destruction of or loss of ecosystems of a given territory (Brochure End Ecocide in Europe: A Citizens' Initiative to give the Earth Rights, 2012)". The collection of signatures is still on going until the $21^{\text {st }}$ January 2014, while this initiative is supported by various members of European Parliament from Germany, Austria, United Kingdom, France, lawyers, directors, professors from well-known universities, institutions and parties, such as: Green Party of England and Wales, European Medical Students' Association in Brussels, International Association for Political Science Students and other professional categories.

The idea for drafting such initiative cames from the fact that nowadays we are the witnesses of the damage and destruction of the planet, breaching our right to have a cleaner earth, and our obligation to protect it and to ensure a sustainable development of it, obligation which is also stated in the Charter of Fundamental Rights of the European Union, providing in the same time a draft of the future directive on Ecocide ${ }^{20}$. This initiative is also based on the efforts took at the European level by adopting the proper legislation ${ }^{21}$ in the field in order to take all the measures needed to ensure an effectively protection of the planet and to criminalise all the persons that area breaching the environmental law.

\footnotetext{
16 http://en.fraternite2020.eu/summary.html.

17 http://ec.europa.eu/citizens-initiative/public/initiatives/ongoing/details/2012/000008/en; http://www.euroedtrust.eu/.

18 The Europe 2020 is a strategy developed by the European Commission having the mutually reinforcing priorities: smart growth by developing an economy based on knowledge and innovation; sustainable growth meaning to promote a more resource efficient, greener and more competitive economy and inclusive growth by fostering a high-employment economy delivering social and territorial cohesion. For more information see http://ec.europa.eu/europe2020/index_en.htm.

19 http://ec.europa.eu/citizens-initiative/public/initiatives/ongoing/details/2013/000002/en; http://ec.europa.eu/citizens-initiative/public /initiatives/ongoing/details/2013/000002/en.

${ }^{20}$ ec.europa.eu/citizens-initiative/public/documents/786.

${ }^{21}$ Directive 2008/99/EC of the European Parliament and of the Council on the protection of the environment through criminal law, published in Official Journal L no.328, 6.12.2008; the EU Biodiversity Strategy 2020 towards implementation, http://consilium.europa.eu/media/1379139/st18862.en11.pdf; the European Parliament Resolution of 20 April 2012, http://ec.europa.eu/environment/nature/biodiversity/comm2006/pdf/EP_resolution_april2012.pdf.
} 


\section{Conclusions}

After the failure of the Convention on the Future on Europe from $2002^{22}$ which in former article $45^{23}$ comprised the first mention of the direct participation of the citizens through a European Citizens' Initiative, the Lisbon Treaty is the second major European treaty that recognises this political right in the benefit of the citizens, creating all the legal premises to adopt the secondary legislation, namely the Regulation (EU) no.211/2011, as a brand new transnational instrument.

I strongly believe that the proper implementation of this instrument will bring only benefits both for European Union, as an entity, and for almost 500 million citizens, which from now on are acting as "co-authors" in the European legislative process but not as main actors, by promoting the most relevant and stringent initiatives, with cross-border element, for the entire European society, encouraging debates on various issues in many fields of activity, such as: education, environment, taxes, economy etc.

Analysing the present paper, one question raises, to what extent this instrument can have the power to contribute in a decisive manner to the trans-European debates on the Union beyond the reticence attitude existed until the adoption of the Regulation (EU) no.211/2011, as concerns the active involvement of the citizens (Głogowski and Maurer, 2013).

Finally, the last part of my paper analyses certain citizens' initiatives that have been already registered on the official website of the European Commission, created in this sense through the Regulation. The main criteria envisaged by me, was the date of the registration of the initiative and not its importance, because from my point of view, each of them can change the present life of the European society, can bring something new to our life, in order to make it simpler, clearer, healthier and better.

\section{References}

Petrescu Oana - Mariuca (2013), The Political Citizenship in the Context of the Lisbon Treaty, Romanian Journal of European Affairs, Vol. 13, No. 1, http://www.ier.ro/documente/rjea_vol13_no1/RJEA_2013_vol13_no1_art.3_pdf

Stanislas Adam (2007), Electoral rights under the review of the European Court of Justice: judicial trends and constitutional weaknesses, CYELP 3, http://www.cyelp.com/index.php/cyelp/article/view/41

Vaughne Miller (2012), Recent EU Treaty Amendments and UK Ratification, http://www.parliament.uk/briefing-papers/SN06503

Besson Samantha \& Utzinger André (2008), Toward European Citizenship, Journal of Social Philosophy, Vol. 39 No. 2, Summer 2008, Blackwell Publishing, Inc., http://doc.rero.ch/record/28131/files/Toward_European_Citizenship.pdf

Głogowski Paweł \& Maurer Andreas (2013), The European Citizens' Initiative The European Citizens' Initiative - Chances, Constraints and Limits, Political Science Series no.134, April 2013, http://www.hihs.ac.at/publications/pol/pw_134.pdf

García Luis Bouza, López Víctor Cuesta, Mincheva Elitsa \& Szeligowska Dorota (2012), The European Citizens' Initiative - A First Assessment, College of Europe, Bruges, http://aei.pitt.edu/33631/1/wp24_EG.pdf

Ikeda Ken'ichi, Kobayashi Tetsuro \& Hoshimoto Maasa (2008), Does political participation make a difference? The relationship between political choice, civic engagement and political efficacy, Electoral Studies no.27, http://www.astrid-online.it/Forme-e-st/Studi-ric/IKEDA-KOBAYASHI-HOSHIMOTO-Electoral-Studies-03_08.pdf

Schnapper Dominique (1997), The European Debate on Citizenship, Daedalus collection, The MIT Press

Shaw Jo (2007), E.U. Citizenship and political rights in an evolving European Union, Fordham Law Review, Volume 75, Issue 5

Chalmers Damian, Davies Gareth \& Monti Giorgio (2006), European Union Law: Cases and Materials, second edition, Cambridge University Press

Directive 2008/99/EC of the European Parliament and of the Council on the protection of the environment through criminal law, published in Official Journal L no.328, 6.12.2008

EU Biodiversity Strategy 2020 - towards implementation

European Parliament Resolution of 20 April 2012

European Parliament Resolution of 7 May 2009 requesting the Commission to submit a proposal for a regulation of the European Parliament and of the Council on the implementation of the citizens' initiative

Regulation (EU) no. 211/2011 on the citizens' initiative, published in Official Journal L series no.65 of 11.03 .2011

22 This Convention was a body established by the European Council in December 2001 to produce a draft Constitution for the European Union for the Council to finalise and adopt. The Convention finished its work in July 2003 with their Draft Treaty establishing a Constitution for Europe, Treaty which failed to be ratified by all the Member States, in 2005, by France and the Netherlands, after two decisive referendums.

${ }^{23}$ Former article 45 "The principle of representative democracy" of the Convention on the Future on Europe stated that "every citizen shall have the right to participate in the democratic life of the Union. Decisions shall be taken as openly as possible and as closely as possible to the citizen". 
Regulation no.1/1958 determining the languages, published in Official Journal L $17 / 6.10 .1958$, as amended by Council Regulation (EC) no. 920/2005 of 13 June 2005, published in Official Journal L 156/3 18.6.2005 and Council Regulation (EC) no 1791/2006 of 20 November 2006, published in Official Journal L 363/20.12.2006

The 1976 Decision and Act concerning the election of the representatives of the European Parliament by direct universal suffrage by the citizens

The Strategy Europe 2020

Treaty of Amsterdam

Treaty on European Union

Background speaking points for Zita Gurmai, MEP: "The ECI regulation - the contribution of the European Parliament in Barcelona, 25 March 2011

Brochure "End Ecocide in Europe: A Citizens' Initiative to give the Earth Rights", published on 02.08.2012

Brochure, The European Citizens' Initiative, The Greens/EFA in the European Parliament, Brussels, 2011

http://aei.pitt.edu/942/1/political_tindemans_report.pdf

http://www.google.com/url?sa=t\&rct=j\&q=\&esrc=s\&source=web\&cd=1\&sqi=2\&ved=0CFcQFjAA\&url=http\%3A\%2F\%2Feurlex.europa.eu\%2FLexUriServ\%2FLexUriServ.do\%3Furi\%3DOJ\%3AL\%3A2011\%3A065\%3A0001\%3A0022\%3AEN\%3APDF\&ei= Gy7XT47VBcS50QXDx6SgBA\&usg=AFQjCNH7FVvqt4lypd4aLnBK5k_RC9mvHg.

http://eur-lex.europa.eu/en/treaties/dat/11992E/tif/JOC_1992_224_1_EN_0001.pdf

https://open.dsv.su.se/mod/book/view.php?id=733\&chapterid=5

jeanmonnetchair.uab.cat/docs/ponencia\%20Gurmai.doc

http://www.europarl.europa.eu/sides/getDoc.do?pubRef=-//EP//TEXT+TA+P6-TA-2009-0389+0+DOC+XML+V0//EN

http://ec.europa.eu/citizens-initiative/public/guide

http://ec.europa.eu/citizens-initiative/public/registration/

http://ec.europa.eu/citizens-initiative/public/initiatives/ongoing

http://eur-lex.europa.eu/LexUriServ/site/en/consleg/1958/R/01958R0001-20070101-en.pdf

http://ec.europa.eu/citizens-initiative/public/initiatives/ongoing/details/2012/000001

http://en.fraternite2020.eu/summary.html

http://ec.europa.eu/citizens-initiative/public/initiatives/ongoing/details/2012/000008/en

http://www.euroedtrust.eu/

http://ec.europa.eu/europe2020/index_en.htm

http://ec.europa.eu/citizens-initiative/public/initiatives/ongoing/details/2013/000002/en

ec.europa.eu/citizens-initiative/public/documents/786

http://consilium.europa.eu/media/1379139/st18862.en11.pdf

http://ec.europa.eu/environment/nature/biodiversity/comm2006/pdf/EP_resolution_april2012.pdf 